\title{
NILAI SERAPAN KARBON HUTAN PINUS DI DESA PESSE KECAMATAN DONRI - DONRI KABUPATEN SOPPENG
}

\section{Carbon absorption value of pine Forest in Pesse Village, Soppeng Regency}

\author{
Sultan $^{1}$, Hasanuddin $^{2}$, Husnah Latifah ${ }^{3}$,Nur Awal ${ }^{4}$ \\ Program Studi Kehutanan Fakultas Pertanian Universitas Muhammadiyah Makassar \\ p.84sultan@yahoo.com
}

\begin{abstract}
Carbon is a chemical element that has an atomic number 6 (C6) (National Standardization Agency (ICS), 2011). Plants will reduce carbon dioxide in the atmosphere (CO2) absorbed through the process of photosynthesis and plants will store it in plant tissue. Until the time the carbon is recycled back into the atmosphere, the carbon will occupy one of several carbon pockets. All components of vegetation, whether trees, shrubs, lianas and epiphytes, are part of the aboveground biomass. Below the soil surface, plant roots are also a store of carbon in addition to the soil itself. On peat soils, the amount of carbon deposits may be greater than the carbon deposits that are above the surface. This study aims to calculate the amount of carbon uptake in pine forests (trees, poles, and saplings) in Pesse Village, Donri - Donri District, Soppeng Regency. This research was carried out for two months starting from octoberi until December 2019. The preparatory phase was carried out by selecting the location of the study, namely in the Village of Pesse, Donri-donri District, Soppeng Regency. Based on the results of research on pine forests, it can be concluded that the total biomass is 12,817.84 tons, carbon stock is 6,024.39 and carbon dioxide absorption is 639.14 tons / year with an area of 19.48 production forest land in Pesse Village, Donri-Donri District, Soppeng District with area of $5557.92 \mathrm{Ha}$.
\end{abstract}

Keywords: carbon stock, uptake, biomass

\begin{abstract}
Abstrak
Karbon adalah unsur kimia yang memiliki nomor atom 6 (C6) (Badan Standardisasi Nasional (ICS), 2011) . Tumbuhan akan mengurangi karbon dioksida di atmosfer (CO2) diserap melalui proses fotosintesis dan tumbuhan akan menyimpannya dalam jaringan tumbuhan. Sampai waktunya karbon tersebut tersikluskan kembali ke atmosfer, karbon tersebut akan menempati salah satu dari sejumlah kantong karbon. Semua komponen penyusun vegetasi baik pohon,semak, liana dan epifit merupakan bagian dari biomassa atas permukaan. Dibawah permukaan tanah, akar tumbuhan juga merupakan penyimpan karbon selain tanah itu sendiri. Pada tanah gambut, jumlah simpanan karbon mungkin lebih besar dibandingkan dengan simpanan karbon yang ada di atas permukaan. Penelitian ini bertujuan untuk Menghitung besar nilai serapan karbon pada Hutan pinus (pohon, tiang, dan pancang ) di Desa Pesse Kecamatan Donri - donri Kabupaten Soppeng. Penelitian ini dilaksanakan selama dua bulan mulai dari oktoberi sampai bulan desember 2019. Tahap persiapan yang dilakukan adalah Pemilihan lokasi penelitian yaitu di Desa Pesse Kecamatan Donri-donri Kabupaten Soppeng. Berdasarkan hasil penelitian pada hutan Pinus maka dapat disimpulkan bahwa Biomassa total 12.817,84 Ton, cadangan karbon 6.024,39 dan serapan karbon dioksida 639,14 Ton/tahun dengan luas lahan hutan produksi 19,48 di Desa Pesse Kecamatan Donri-donri Kabupaten Soppeng dengan luas 5557,92 Ha.
\end{abstract}

Kata Kunci : Cadangan karbon, serapan, biomassa 


\section{PENDAHULUAN}

Hutan merupakan penyerap karbon terbesar dan memainkan peranan penting dalam siklus karbon global serta dapat menyimpan karbon sekurang-kurangnya 10 kali lebih besar dibandingkan dengan tipe vegetasi lain (Samsoedin 2009). Pengukuran besar penyerapan $\mathrm{CO}_{2}$ oleh pohon dapat diduga dari biomassa pohon (Aminudin 2008). Kerusakan hutan, perubahan iklim, dan pemanasan global secara tidak langsung menyebabkan manfaat hutan berkurang. Upaya menguranginya dengan cara penanaman vegetasi pada lahan yang kosong atau merehabilitasi hutan akan membantu menyerap kelebihan $\mathrm{CO}_{2}$ diatmosfer (Adinugroho, 2006).

Teknologi penginderaan jarak jauh merupakan salah satu cara yang efektif dalam mendukung penyajian hasil pengukuran jumlah biomassa dan cadangan karbon pada suatu kawasan dengan tipe penggunaan lahan yang berbeda-beda serta pemantauan perubahan lahannya dari waktu ke waktu. Sejalan dengan perkembangan teknologi penginderaan jauh (remote sensing), satelit yang ada cukup memadai untuk memantau kondisi terkini tentang sumber daya alam (Dahlan, et al, 2005). Data hasil perubahan penggunaan lahan yang telah diintegrasikan dengan data hasil pengukuran karbon yang diwakili oleh beberapa skala plot dan telah melalui pengolahan serta analisis dengan menggunakan Sistem Informasi Geografis (SIG) dapat memberikan gambaran pendugaan perubahan cadangan karbon dari waktu ke waktu yang dapat dijadikan sebagai baseline cadangan karbon.

Berdasarkan hal tersebut di atas maka diperlukan suatu penelitian nilai serapan karbon pada hutan pinus di Kecamatan Donri-Donri Kabupaten Soppeng. Adapun tujuan penelitian ini adalah untuk menghitung besar nilai serapan karbon pada Hutan pinus (pohon, tiang, dan pancang ) di Desa Pesse Kecamatan Donri - donri Kabupaten Soppeng.
Volume 2 Nomor 1 Juli 2020:32-36 METODE PENELITIAN

Penelitian ini dilaksanakan selama kurang lebih dua bulan yaitu mulai bulan Oktober sampai bulan Desember 2019 di Desa Pesse Kecamatan Donri - Donri Kabupaten Soppeng.

Alat dan bahan yang digunakan di lapangan dalam penelitian ini adalah roll meter, Tali raffia, Gps, Alat tulis menulis, Kamera, Tally sheet, Peta.

Pengambilan sampel dilakukan dengan menggunakan teknik sampling. Data cadangan karbon dari tutupan/penggunaan lahan dilakukan pada Hutan Produksi dengan luas $19,48 \times 2 \%=\frac{0,487}{0,04}=12$ Plot yang telah ditentukan sebelumnya. Untuk menghitung total cadangan karbon dari tutupan/penggunaan lahan didasarkan pada kandungan biomassa dari pancang, tiang dan pohon.

Penentuan letak plot contoh pengukuran serapan karbon dilakukan pada masing-masing penutupan lahan dengan Ukuran plot untuk tiap tingkatan pertumbuhan vegetasi adalah. Biomassa pohon dihitung dengan menggunakan Rumus Nilai Koefisien allometrik ( $a$ dan b ) untuk perhitungan biomassa bagian atas berdasarkan spesies pohon dengan menggunakan rumus perhitungan $\mathrm{Y}=\boldsymbol{\pi} . \mathrm{D}^{\mathrm{b}}$ yang telah banyak digunakan oleh penelitipeneliti sebelumnya yang pengukurannya diawali dengan menebang dan menimbang pohon (Hardjana.A.K, 2011).

\section{HASIL DAN PEMBAHASAN}

\section{Biomassa Hutan Pinus}

Perhitungan Biomassa, Karbon dan Serapan Karbon Dioksida total vegetasi pada tingkat pohon, tiang dan pancang dengan kriteria tinggi mulai dari $1,5 \mathrm{~m}$ dengan diameter $\geq 10 \mathrm{~cm}$. 


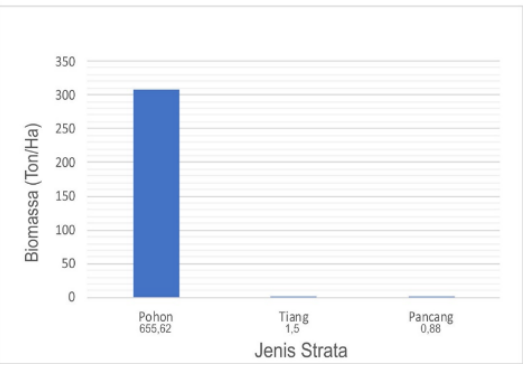

Gambar 1. Grafik Nilai Persentase Rata-Rata Biomassa Pada Hutan Pinus.

Gambar 1 dapat diketahui bahwa biomassa hutan pinus pada tingkat pohon, tiang dan pancang.Tingkat pohon jumlah biomassa yang lebih besar, karena pohon memiliki diameter yang lebih besar dengan total jumlah biomassanya adalah 655,62 Ton/ha. Untuk tingkat tiang jumlah Biomassanya adalah 1,5 Ton/ha dan Jumlah Biomasssa pada tingkat pancang adalah 0,88 . Total biomassa pada hutan pinus adalah 685 Ton/ha.

\section{Karbon Hutan Pinus}

Cadangan karbon pada hutan pinus ditentukan berdasarkan nilai total semua biomassa vegetasi pada hutan pinus dihasilkan dari persamaan nilai koefisien a dan b, kemudian melalui pendekatan biomassa dengan asumsi bahwa $47 \%$ dari biomassa adalah karbon yang tersimpan Hal ini dapat dilihat pada Gambar2.

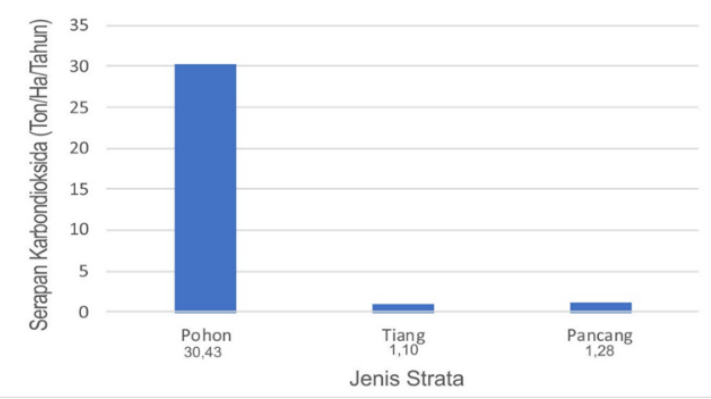

Gambar 3. Grafik Nilai Persentase Rata-Rata Serapan Karbon Dioksida Pada Hutan Pinus.

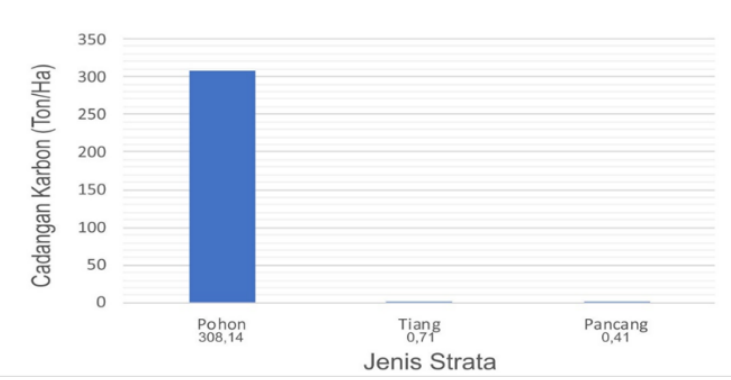

Gambar 2. Grafik Nilai Persentase Rata-Rata Cadangan Karbon Pada Hutan Pinus.

Kandungan karbon Hutan Pinus terdapat pada Gambar 2, Pohon mempunyai Cadangan karbon adalah 308,14 Ton/ha, Kandungan karbon rata-rata tingkat tiang adalah 0,71 Ton/ha, sedangkan jumlah kandungan karbon pada tingkat pancang adalah 0,41 Ton/ha. Total cadangan karbon rata-rata pada lokasi hutan pinus dalam penelitian ini sebesar 309,26 Ton/ha

\section{Serapan Karbon Dioksida Hutan Pinus}

Hutan pinus mempunyai Serapan Karbon Dioksida rata-rata dapat diketahui berdasarkan nilai total pertumbuhan biomassa per tahun vegetasi pada hutan pinus yang dihasilkan dari persamaan nilai koefisien a dan $b$, kemudian biomassa dikalikan dengan faktor konversi serapan karbon dioksida (1,4667), Dapat dilihat pada Gambar 3.

Hutan pinus mempunyai Potensi serapan karbon dioksida rata-rata dapat dilihat pada Gambar 3. Berdasarkan Gambar 3, serapan karbon dioksida hutan pinus per tahun pada tingkat pohon, 30,43 Ton/ha per tahun tingkat tiang, adalah 1,10 Ton/ha per tahun dan untuk tingkat pancang, 1,28 Ton/ha. Total serapan karbon dioksida pada lokasi hutan pinus adalah 32,81 Ton/ha per tahun.

Biomassa Total, Cadangan Karbon dan Serapan Karbon Dioksida Hutan Pinus Desa Pesse, Kecamatan Donri -Donri, Kabupaten Soppeng 
Volume 2 Nomor 1 Juli 2020:32-36

Tabel 1. Biomassa Total, Cadangan Karbon dan Serapan Karbon Dioksida Di Desa Pesse Kecamatan Donri-donri Kabupaten Soppeng.

\begin{tabular}{|c|c|c|c|c|c|c|c|c|}
\hline No & $\begin{array}{c}\text { Jenis } \\
\text { Penutupan } \\
\text { Lahan }\end{array}$ & $\begin{array}{c}\text { Luas } \\
\text { (Ha) }\end{array}$ & $\begin{array}{c}\text { Biomassa } \\
\text { Rata-rata } \\
\text { (Ton/ha) }\end{array}$ & $\begin{array}{c}\text { Cadangan } \\
\text { Karbon } \\
\text { Rata-rata } \\
\text { (Ton/ha) }\end{array}$ & $\begin{array}{c}\text { Serapan } \\
\text { Karbon } \\
\text { Dioksida } \\
\text { Rata-rata } \\
\text { ton/ha per } \\
\text { tahun) }\end{array}$ & $\begin{array}{c}\text { Biomassa } \\
\text { Total (Ton) }\end{array}$ & $\begin{array}{c}\text { Cadangan } \\
\text { Karbon } \\
\text { Total } \\
\text { (Ton) }\end{array}$ & $\begin{array}{c}\text { Serapan } \\
\text { Karbon } \\
\text { Dioksida } \\
\text { Total } \\
\text { (Ton/thn) }\end{array}$ \\
\hline 1 & $\begin{array}{c}\text { Hutan } \\
\text { produksi }\end{array}$ & 19,48 & 658 & 309,26 & 32,81 & $12.817,84$ & $6.024,39$ & 639,14 \\
\hline
\end{tabular}

Sumber : Data Primer Setelah Diolah 2017

Berdasarkan hasil observasi di Desa Pesse Kecamatan Donri- donri Kabupaten Soppeng. Biomassa Total, Cadangan Karbon dan Serapan Karbon Dioksida dihitung dengan mengalikan nilai Biomassa rata-rata, Cadangan Karbon dan Serapan Karbon Dioksida dengan luas penutupan lahan. Serapan karbon Dioksida pada penelitian ini sebesar 639,14 ton/thn lebih tinggi jika dibandingkan dengan hasil penelitian Marimpan (2010) pada tanaman Eucalyptus urophylla di hutan alam sebesar 458,91 ton/ha. Tingginya serapan karbon yang dihasilkan pinus karena pohon pinus merupakan vegetasi yang memliki kanopi atau tutupan tajuk yang besar sehingga dengan jumlah daun yang banyak mampu menyerap karbon yang banyak pula. Perbedaan ini dipengaruhi oleh kemampuan ekosistem hutan menyimpan dan menyerap karbon berdasarkan jenis vegetasi, komposisi vegetasi, topografi dan tempat tumbuh (Paembonan, 2012)

\section{KESIMPULAN}

Berdasarkan hasil penelitian serapan karbon rata-rata pada hutan pinus di desa pesse kecamatan donri - donri kabupaten soppeng dengan luas hutan Produksi 19,48 Ha adalah 32,81 Ton/ha pertahun dan total serapan karbon hutan pinus di desa pesse kecamatan donri - donri kabupaten soppeng adalah 639,14 Ton/tahun dengan luas desa pesse kecamatan donri - donri kabupaten soppeng $5557,92 \mathrm{Ha}$.

\section{DAFTAR PUSTAKA}

Adinugroho WC, Syahbani I, Rengku MT, Arifin Z, Mukhaidil. 2006. Pendugaan karbon dalam rangka pemanfaatan fungsi hutan sebagai penyerap karbon. Samboja [ID]: Balai Penelitian Kehutanan Samboja.

Aminudin. 2008. Kajian potensi cadangan karbon pada pengusahaan hutan rakyat (studi kasus: hutan rakyat Dengok, kecamatan Playen, kabupaten Gunung Kidul) [tesis]. Sekolah Pascasarjana. Bogor [ID]: Institut Pertanian Bogor.

Dahlan, Jaya INS, Istomo. 2005. Estimasi Karbon Tegakan Acacia mangium Willd. Menggunakan Citra Landsat ETM+ dan SPOT-5: (Studi kasus di BKPH Parung Panjang KPH Bogor). Di dalam: "Pemanfaatan Efektif Penginderaan Jauh Untuk Peningkatan Kesejahteraan Bangsa" Pertemuan Ilmiah Tahunan MAPIN XIV Institut Teknologi Sepuluh Nopember. Surabaya, 14 - 15 September 2005. hlm 108-117.

IGES, 2006. Clean Development Mechanism. Panduan MPB di Indonesia,Terjemahan oleh ICER Indonesia. Kementerian Lingkungan Hidup. Jepang. Tokyo.

Kitredge, 1994 dalam Hardjana, A. K. (2011). MEMBANGUN PERSAMAAN ALOMETRIK BIOMASSA TANAMAN Shorea Leprosula DI AREAL IUPHHK-HA PT. ITCIKU KALIMANTAN TIMUR. Jurnal 
Penelitian

Ekosistem

Dipterokarpa, 5(1), 1-10.

MARIMPAN, L. S., \& Purwanto, I. R. H. (2010). Inventore hutan alam jenis ampupu (Eucalyptus urophylla) dalam menghasilkan volume kayu batang, biomassa dan karbon hutan (Doctoral dissertation, [Yogyakarta]: Universitas Gadjah Mada).
Paembonan, S.A. (2012). Hutan Tanaman dan Serapan Karbon. Masagena Press. Makassar.

Samsoedin I, Dharmawan IW, Siregar CA. 2009. Potensi biomassa karbon pada hutan alam dan hutan bekas tebangan setelah 30 tahun di Hutan Penelitian Malinau, Kalimantan Timur. Jurnal Penelitian Hutan. Vol. 6: (4-12). Bogor [ID]: Pusat Penelitian Hutan dan Konservasi Alam. 